\title{
EFFECT OF SECONDARY \\ ALTERATION ON BIOMARKERS \\ PROTECTED BY STRUCTURES OF ASPHALTENES FROM BRAZILIAN CRUDE OILS \\ JURAL, P.A. ${ }^{1}$; LIMA, A.L.B ${ }^{1}$; GONZÁLEZ, M.B ${ }^{1}$; SILVA, T.F. ${ }^{1}$; PERALBA, M.C. ${ }^{1}$; LENZ, R.L. '; DUBOIS, D.S. ${ }^{2}$
}

${ }^{1}$ Universidade Federal Rio Grande do Sul, Avenida Bento Gonçalves 9500, CEP 91509900 Porto Alegre, Brazil.

${ }^{2}$ Centro de Pesquisa e Desenvolvimento Leopoldo, A. Miguez CENPES/PETROBRAS Ilha do Fundão, Rio de Janeiro, RJ 21941-909, Brazil

Asphaltenes, which can be considered as fragments of kerogen, can occlude and protect hydrocarbon compounds from secondary alterations (e.g., biodegradation), that occurs in petroleum reservoirs. The objective of this study was to characterize the distribution of hydrocarbons occluded and adsorbed by asphaltenes structures, and compare, in a geochemical approach, with those free in the original crude oil. Asphaltenes from thirteen Brazilian crude oils were obtained and submitted to mild oxidative treatment to disrupt their structure, releasing occluded hydrocarbons. The results indicate a similarity in the geochemical parameters from free and adsorbed hydrocarbons. Different values were observed for the occluded biomarkers (e.g., distribution of $\mathrm{C}_{27}, \mathrm{C}_{28}$ and $\mathrm{C}_{29}$ steranes and terpane ratios) which suggest mixing of different sources and/or thermal maturity inputs. Biodegraded samples, lacking $n$-alkanes in the free and adsorbed fractions, have shown predominance of low and higher molecular weight linear paraffins, from $n \mathrm{C}_{16}$ to $n \mathrm{C}_{33}$, in the occluded fractions. These observations indicate that occluded hydrocarbons are a useful tool in petroleum systems studies, especially where biomarkers are affected by any degree of secondary alteration. 